\title{
Data Collection for Public Space Quality Evaluation
}

\section{Získávání dat pro hodnocení kvality veřejných prostranství}

\author{
aPavla Kilnarová, bHoráková Eva \\ aUstav urbanismu, Fakulta architektury, Vysoké učení technické v Brně, \\ školitel: doc. Ing. arch. Gabriel Kopáčik, Dr. \\ bÚstav prostorové tvorby, Fakulta architektury, Vysoké učení technické v Brně, \\ školitel: doc. Ing. arch. Jiří Palacký, Ph.D.
}

\begin{abstract}
Urban spaces hold a lot of essential public functions and play an irreplaceable role in the operating of a modern city. Therefore, monitoring their quality in relation to social needs and the way of its utilization are very important. There are some empirical methods suitable for long-term observation based on direct observation of users' behaviour in a space that require a rather high number of researchers and are time-consuming. The most frequently used empirical methods for studying public life are the monitoring of pedestrian movement, the monitoring of traffic movement, path tracking and the monitoring of people movement intensity based on the local amenities.
\end{abstract}

The aim of this paper is to introduce appropriate data collecting methods for the realm of public space evaluation, applied to a case study of the Náměstí Republiky square in Brno, Czech Republic, to discover whether we can observe public squares without physically being there and to compare virtually gathered information with the results from empirical observations.

KEYWORDS: public space; empirical observation; life quality; data collection methods; quality evaluation; Brno

ABSTRAKT: Veřejná prostranství hrají nezastupitelnou roli ve fungování měst, zastávají mnoho důležitých funkcí a je z dlouhodobého hlediska důležité monitoro- 
vat jejich kvalitu. Empirická pozorování jsou nezbytná pro vhodné stanovení podmínek strategického rozvoje veřejných prostranství, avšak náročná na čas a lidské zdroje. Nejčastějšími metodami empirického pozorování, které jsou dnes použíány $\mathrm{k}$ analýze života na veřejném prostranství, jsou sledování pěšího pohybu osob (PPO) a pohybu dopravních prostředků (PDP), trasování osob prostorem (TOP) a zjištování intenzity pohybu osob v návaznosti na př́tomnost různých druhů městské vybavenosti (IPO). Př́spěvek si klade za cíl představit vhodné metody sběru dat a kritéria hodnocení na př́ípadové studii náměstí Republiky ve městě Brně a zjistit, zda je možné informace o zkoumaných veřejných prostranstvích zjištovat bez jejich návštěvy a jaká je relevance těchto dat $\mathrm{v}$ porovnání s výsledky přímého empirického pozorování na místě.

KLÍČOVÁ SLOVA: veřejná prostranství; empirické pozorování; kvalita života; metody sběru dat; hodnocení kvality; Brno

\section{Úvod}

Kvalita veřejných prostranství je odvozena od potřeby vytvářet a zvyšovat kvalitu života obyvatel měst. (Senlier, 2009) Kvalitní prostor by měl splňovat základní požadavky na možnost pohybu i pobytu, měl by být dostupný a bezpečný. (Gehl, 2012) Dosud bylo vytvořeno přes sto různých definic kvality života ve městech. (Gullone, 1999) Definice se shodují v tom, že je možné definovat subjektivní a objektivní prvky kvality. Objektivní prvky zahrnují aspekty života získávané nejčastěji ze statistik a přehledů, zatímco subjektivní zahrnují otázky spokojenosti a štěstí. K dlouhodobému sledování kvality života ve veřejném prostoru se nejčastěji používají metody založené na př́mém empirickém pozorování chování lidí v prostoru, jak je popsali ve svých pracích Jan Gehl a William H. Whyte. (Gehl, 2013; Whyte, 1980)

Empirická pozorování jsou nezbytná pro vhodné stanovení podmínek strategického rozvoje veřejných prostranství (Bowler, 2010), avšak náročná na čas a lidské zdroje. Aby bylo možné detailně popsat chování lidí v prostoru, je potřeba dodržet dvě základní podmínky - pozorování provádět $\mathrm{v}$ dostatečně dlouhém časovém úseku a správně určit účel pobytu uživatelů v daném prostoru.

Nejčastějšími metodami empirického pozorování, které jsou dnes používány k analýze života na veřejném prostranství, jsou sledování pěšího pohybu osob (PPO), sledování pohybu dopravních prostředků (PDP), trasování osob prostorem (TOP) (Gehl, 2013) a zjištování intenzity pohybu osob v návaznosti na př́tomnost různých druhů městské vybavenosti (IPO). (Whyte, 1980) 
Pro tyto metody je charakteristická fyzická prrítomnost v prostoru, a proto autoři rozvíjí metodu sdruženého sběru informací o chování uživatelů veřejného prostoru založenou na využití otevřených dat s možností hodnocení místa na dálku. Cílem článku je popsat možné př́stupy ke zkoumání kvality života na veřejných prostranstvích a pomocí rešerše existujících metod zjistit, zda je možné informace o zkoumaných veřejných prostranstvích zjištovat bez jejich návštěvy a jaká je relevance těchto dat v porovnání s výsledky přímého empirického pozorování na místě. Tato data jsou následně využitelná k sestavování zadání revitalizací a projektů studií veřejných prostranství.

\section{Lokalita - náměstí Republiky}

Náměstí Republiky je náměstí v Brně, v městské části Brno-sever, v katastru Husovic. Náměstí podlouhlého tvaru vychází z Dukelské třídy a na opačném konci jej uzavírá Vranovská ulice. Přibližně v půli jej kříží ulice Nováčkova, která jej dělí do dvou částí o různé šířce.

Dominantou náměstí je v širší části mezi Nováčkovou a Vranovskou ulicí kostel Nejsvětějšího srdce Páně. Pro potřeby výzkumu je plocha náměstí zmenšena o plochu okolo kostela a za jeho závěrem. Zkoumaná plocha je vymezena hranou okolních budov, v místě ulic je hranicí lokality nejkratší přímá spojnice nárožních budov.

Pro empirická pozorování je v tomto konkrétním př́ípadě potřeba 3 pozorovatelů, kteří náměstí pozorují po dobu 16 hodin.

\section{Metody zkoumání}

Metoda empirického pozorování je aplikována dle pravidel sestavených na základě publikace Jana Gehla (2013). Data jsou získávána ve zkoumaném prostoru po dobu 16 hodin od 7:00 ráno do 23:00, a to ve všední den (v úterý, ve středu nebo ve čtvrtek), podmínky pro pozorování jsou omezeny aktuálním počasím, které by mělo být slunečné s teplotami nad $20^{\circ} \mathrm{C}$. (Mehta, 2016) Zkoumaný prostor je každou hodinu analyzován pozorovatelem a pozorované jevy jsou zaznamenávány do předem připraveného záznamového archu.

Městská data lze získávat nejen sběrem na místě, ale i sběrem otevřených dat a volně dostupných podkladů z internetu. Otevřená data jsou informace a čísla volně dostupné na internetu ve strukturované strojově čitelné podobě, což umožňuje jejich hromadné počítačové zpracování, $\mathrm{k}$ němuž jejich vydavatel poskytl právní svolení. (Sashinskaya, 2015) Mezi otevřená data patři data mobilních operátorů a data ze sociálních sítí nebo z vyhledávačů. Přestože jsou data anonymizována, mají svou výpovědní hodnotu. Jejich velkou předností je možnost jejich počítačového zpracování, jelikož velkoobjemová 
data by se jen těžko dala zpracovat ručně. (Stopczynski, 2014) Informace získané z otevřených dat a tradičního ručního sběru dat se liší. Další možností je automatizovaný sběr dat jako doplněk $k$ datům, která jsou uveřejňována např́íklad jen pro celou základní sídelní jednotku. Výhodou této metody je, že snižuje počet pozorovatelů, nicméně některá pozorování zatím jinak než na místě provádět nelze.

\section{Metoda IPO}

Do ortofotomapy náměstí, která zobrazuje hranici zkoumaného prostoru a všechny mobiliářové prvky i hrany terénu vyskytující se na náměstí, jsou jednou za hodinu zaznačeny všechny stacionární aktivity, které uživatelé v daném okamžiku provádí. Základním pravidlem přitom je započítat každého $\mathrm{z}$ uživatelů pouze jednou. Zaznamenávány jsou aktivity typu stojí, sedí na lavičce, sedí mimo lavičku, sedí na zahrádce restaurace apod. Tuto činnost vykonává pozorovatel č. 3. Získaná informace se skládá ze 3 faktů - 1. umístění vykonávané aktivity, 2. typ vykonávané aktivity, 3. časový rámec.

Tuto metodu je velmi těžké nahradit vzdáleným př́stupem, protože $\mathrm{v}$ reálném čase zatím není možné zjištovat aktivity uživatelů v čase. Jednou z variant je analyzování záznamů z městských kamer. Další možností je fotografování místa v určené hodiny a analýza fotografií, $\mathrm{k}$ jejímuž využití byl zapotřebí jeden pozorovatel, nicméně v rámci městského zkoumání by jistě šla vyřešit fotobuňkou. Vyhodnocování fotografií ale dále probíhá manuálně nebo za pomoci algoritmů R-CNN (Williams, 2017), které vyžadují programátorskou zkušenost. V tomto výzkumu zatím využití algoritmů R-CNN nebylo testováno. Jako možný zdroj pro sběr dat přímo od uživatelů náměstí se v tomto př́padě nabízí aplikace Instagram, do které její uživatelé nahrávají snímky s označením jejich lokace a mnohdy i aktivity nebo konkrétního navštíveného místa, restaurace, kavárny, památky. Tato data je možné dále automatizovat a vytvářet jakýsi digitální obraz města, jeho digitální identitu, jsou ukazatelem atraktivity místa. (Boris T. van Zanten, 2016) Podmínkou je, aby místo bylo dostatečně atraktivní, což u vybrané lokality náměstí Republiky asi nebude splněno. Aplikace je také omezená na určité věkové skupiny.

\section{Metoda PPO}

Jsou počítáni všichni chodci, kteří vstoupí do prostoru náměstí, a všechny dopravní prostředky, které vjedou do prostoru náměstí. Tento údaj je vyčíslen vždy za časový úsek 15 minut v rámci každé pozorované hodiny. $Z$ tohoto počtu je následně aritmetickým průměrem stanoveno celkové množství návštěvníků náměstí v jednotlivých hodinách a dopravní zátěž. Tuto činnost vykonává pozorovatel č. 1 pro vstupy označené jako $\mathrm{A}, \mathrm{B}, \mathrm{C}$ a D, pozorovatel č. 2 pro vstup $\mathrm{F}$ a pozorovatel č. 3 pro vstup $\mathrm{E}$. 
počet připojených telefonů. Každý telefon v okruhu 30 metrů, který má zapnutý Wi-Fi přijímač, se automaticky pokusí k Wi-Fi připojit. (Stopczynski, 2014) Podobně je Wi-Fi využíváno v obchodních centrech. (Li, 2011) V našem př́ípadě jsou telefony připojené déle než 2 hodiny pravděpodobně v okolních budovách, telefony připojené na krátký časový úsek se nacházejí v projíždějících automobilech. U těchto zařízení se dá sledovat i síla signálu, to znamená, že při zapojení více Wi-Fi vysílačů je možné sledovat směr pohybu lidí. $\mathrm{V}$ prŕpadě náměstí Republiky byly použity dva vysílače u pozorovatelů 1 a 2 . Aby bylo možné data kalibrovat, probíhá měření současně s empirickým pozorováním. Při trvalém užíání by bylo možné vysílač integrovat například do lamp veřejného osvětlení, protože potřebuje napájení. Výhodou těchto zařízení je, že na rozdíl od různých fitness aplikací nevyžadují žádnou interakci s procházejícími chodci, žádné instalace ani speciální přípravu, nenarušují tedy nijak veřejný život na prostranství.

\section{Metoda PDP}

Je monitorován počet parkujících aut v prostoru náměstí. Dále je do mapy zaznamenávána poloha parkujících automobilů a to, zda parkují na vyhrazených plochách, nebo mimo vyhrazená území. Počet parkujících aut je porovnáván s celkovou kapacitou parkovacích stání v prostoru náměstí. Tuto činnost vykonává pozorovatel č. 3 .

Město Brno vyvíjí aplikaci, která sleduje obsazenost jednotlivých parkovacích ploch - funguje zatím ve zkušebním provozu a pouze pro centrum města. V ostatních lokalitách nezbývá než postupovat pomocí podobné metody, jako je monitoring aktivit, a analyzovat obsazenost parkování na časosběrných fotografí́ch.

\section{Metoda TOP}

Do slepé mapy je zaznamenáván pohyb 100 náhodně vybraných chodců v průběhu celého časového úseku pozorování. Tuto činnost vykonává pozorovatel č. 3.

Na trasování obyvatel, nejen chodců, ale i cyklistů, existuje aplikace Strava, která zaznamenává trasy lidí s krokoměrem at už při chůzi, nebo sportu. Její výhoda tkví ve velkém množství dat. Aplikace neukazuje data „real time“, ale ukazuje nejčastější trasy, což je pro účely územního plánování ideální. Je nicméně závislá na datech od uživatelů. V některých lokalitách jsou tak trasy omezeny. (Selala, 2016)

\section{Závěr}

Z výše prezentovaných metod vyplývá, že existují možná řešení, jak některá z dat dosud získávaných pouze pozorováním na místě nahradit volně př́stupnými otevřenými daty. Pro ideální výsledky je zatím nezbytné, aby byly obě metody kombinovány, 
protože se nedá př̌edpokládat, že by bylo k dispozici dostatečné množství podrobných dat pro celá území měst.

Konkrétní výzkum zaměřený na data týkající se náměstí ve městě Brně zatím stále probíhá. $V$ rámci dalšího postupu je nezbytné provést výzkum ve více lokalitách $\mathrm{v}$ různých částech města, aby se potvrdila účinnost zvolených metod. Proběhne verifikace výsledků získaných $\mathrm{v}$ rámci jedné lokality i srovnání dat získaných v různých lokalitách. $V$ závěru bude navržena vhodná kombinace obou přístupů (empirického pozorování a získávání otevřených dat online) pro hodnocení kvality života na veřejných prostranstvích. Po verifikaci kombinovaných výsledků a vyvinutí spolehlivého prototypu by mělo být možné začít využívat digitálního sběru informací o lokalitách.

\section{Literatura}

BORIS T. VAN ZANTEN, Derek B. VAN BERKEL, Ross K. MEENTEMEYER, Jordan W. SMITH, Koen F. TIESKENS a Peter H. VERBURG, 2016. Continental-scalequantificationoflandscapevaluesusingsocial media data. ProceedingsoftheNationalAcademyofSciencesofthe United Statesof America. Vol.113(46), 12974-12979. DOI: 10.1073/pnas.1614158113.

BOWLER, Diana E., Lisette BUYUNG-ALI, Teri M. KNIGHT a Andrew S. PULLIN, 2010. Urban greening to cooltowns and cities: A systematicreviewoftheempirical evidence. Landscape and Urban Planning. 97(3), 147-155. DOI: 10.1016/j.landurbplan.2010.05.006. ISSN 01692046. Dostupné také z: http://linkinghub.elsevier. com/retrieve/pii/S0169204610001234

GEHL, Jan, 2012. Města pro lidi. Brno: Partnerství. ISBN 978-80-260-2080-6.

GEHL, Jan a Birgitte SVARRE, 2013. How to study public life. London: Island Press. ISBN 16-109-1423-6.

GULLONE, Eleonora a Robert A. CUMMINS, 1999. TheComprehensiveQualityofLifeScale: A PsychometricEvaluationwithan Adolescent Sample. BehaviourChange. 16(02), 127-139. DOI: 10.1375/bech.16.2.127. ISSN 0813-4839. Dostupné také z: https://www.cambridge.org/core/product/identifier/S0813483900000139/ type/journal_article

MEHTA, Vikas, 2016. LivelyStreets. JournalofPlanningEducation and Research. 27(2), 165-187. DOI: 10.1177/0739456X07307947. ISSN 0739-456X. Dostupné také z: http://journals.sagepub.com/doi/10.1177/0739456X07307947

LI, Ji Yun a Hao PANG, 2011. Shopping PathAnalysis and AdministrationBased on WIFI Data. AdvancedMaterialsResearch. 403-408, 2518-2521. DOI: 10.4028/ www.scientific.net/AMR.403-408.2518. ISSN 1662-8985. Dostupné také z: https://www.scientific.net/AMR.403-408.2518

SASHINSKAYA, Maria, 2015. Allyouwant to knowabout open data. Brussels: [Createspace Independent PublishingPlatform]. ISBN 978-1542893961. 
SELALA, M. K. a W. MUSAKWA, 2016. THE POTENTIAL OF STRAVA DATA TO CONTRIBUTE IN NON-MOTORISED TRANSPORT (NMT) PLANNING IN JOHANNESBURG. ISPRS - InternationalArchivesofthePhotogrammetry, RemoteSensing and SpatialInformationSciences. XLI-B2, 587-594. DOI: 10.5194/ isprs-archives-XLI-B2-587-2016. ISSN 2194-9034. Dostupné také z: http://www. int-arch-photogramm-remote-sens-spatial-inf-sci.net/XLI-B2/587/2016/

SENLIER, Nihal, Reyhan YILDIZ a E. Diğdem AKTAŞ, 2009. A PerceptionSurveyfortheEvaluationof Urban QualityofLife in Kocaeli and a ComparisonoftheLifeSatisfactionwiththeEuropeanCities. SocialIndicatorsResearch. 94(2), 213-226. DOI: 10.1007/s11205-008-9361-1. ISSN 0303-8300. Dostupné také z: http://link. springer.com/10.1007/s11205-008-9361-1

STOPCZYNSKI, Arkadiusz, Vedran SEKARA, Piotr SAPIEZYNSKI, Andrea CUTTONE, Mette My MADSEN, Jakob Eg LARSEN, Sune LEHMANN a MORENO, 2014. MeasuringLarge-ScaleSocialNetworkswithHighResolution. PLoS ONE. 9(4), e95978-. DOI: 10.1371/journal.pone.0095978. ISSN 1932-6203. Dostupné také z: http://dx.plos.org/10.1371/journal.pone.0095978

WHYTE, William Hollingsworth, 1980. Thesociallifeofsmallurbanspaces. ConservationFoundation. ISBN 0891640576.

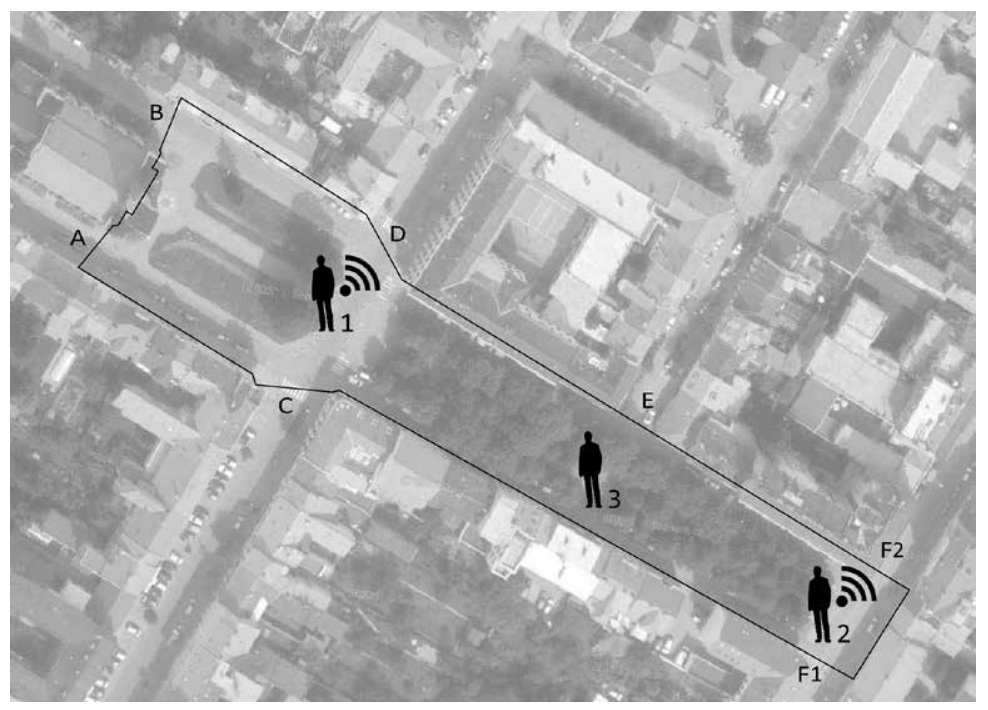

Obr. 1. Rozmístění pozorovatelů na ploše pozorovaného náměstí (zdroj: archiv autorů) 


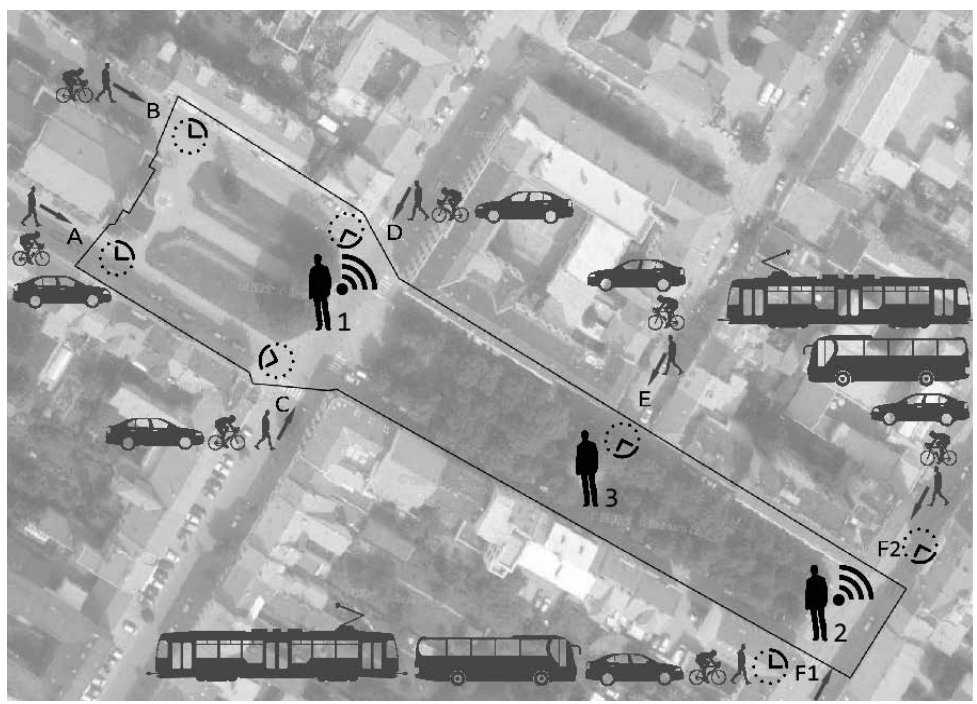

Obr. 2. Sledované druhy dopravy u vstupů do prostoru pozorovaného náměstí (zdroj: archiv autorů)

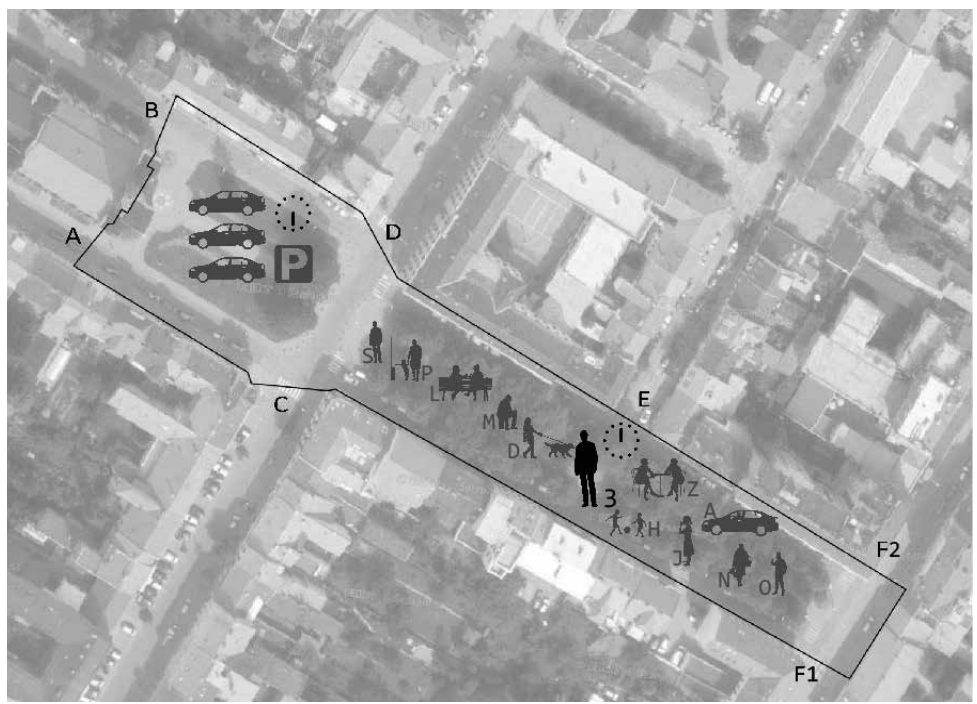

Obr. 3. Sledované aktivity v prostoru pozorovaného náměstí (zdroj: archiv autorů) 